\title{
The European Union's Human Security Discourse: Where are we now? ${ }^{1}$
}

George Christou*

Department of Politics and International Studies, University of Warwick

\begin{abstract}
The language of human security has been prominent in the EU's official discourse for a number of years. However, whilst it has been promoted as a new approach for the EU in the development of its security and defence policy, the aim of this article is to assess the extent to which it actually features in the EU's contemporary strategic discourse and practice. It seeks to uncover where and how the concept is spoken within the EU's institutional milieu, how it is understood by the relevant policy-makers in the EU, and the implication of this across key areas of human security practice. It is argued in the article that human security has not been embedded as the driving strategic concept for CSDP in an era of crisis and change in Europe and beyond and that the prospects for this materialising in the near future are rather thin.
\end{abstract}

\section{KEY WORDS: European Union, Human Security, Responsibility to Protect (R2P), Strategic narrative,}

\section{Introduction}

In exploring the when and how of the emergence of the language of human security it is critical that we understand the agency that drove, and to a certain degree, continues to drive the human security agenda in Europe and the EU. Most salient here are key individuals such as Javier Solana who began his advocacy of a human

"e-mail: g.christou@warwick.ac.uk 
security as NATO Secretary General - and continued this advocacy when taking up the post of EU High Representative for Common Foreign and Security Policy in the post-Amsterdam Treaty era (after 1999). Benita Ferrero-Waldner, Commissioner for External Relations and European Neighbourhood Policy (until 2009), has also consistently campaigned for a human security approach to guide EU foreign and security policy, concentrating her primary attention on matters related to children as the victims of armed conflicts as well as on educational programmes devoted to human rights $(2005,2006)$. Indeed, Solana was behind the commissioning of the Human Security Study Group - which has been the main advocacy group - or epistemic community - constructing and communicating a human security doctrine for the EU - that is, as a frame for the EU's actions in global security. Indeed in May 2010 the Group produced a Report outlining a 'Human Security Architecture for Europe' in the context of EU-Russia relations, and more specifically, Medvedev's proposed European Security Treaty. Other groups such as the Human Security Network, set up by the foreign ministers of twelve countries in Norway in 1999, have also been active, and to a certain degree successful in their advocacy of a human security approach not just on a European, but international scale (The Importance of Human Security in a Globalised World, 2007)

Whilst there is no doubt - as acknowledged by policy makers, practitioners and academics alike - that human security is 'visible' in and across the many dimensions of EU external policies, even certain individuals that were involved in the writing of the Barcelona Report of the Study Group on European Security Capabilities (A Human Security Doctrine for Europe 2004) and the subsequent Madrid Report (A European Way of Security 2007), have more recently reflected 
on how far the human security agenda has actually penetrated, and been embedded, in the high-level discourse of key international organisations and countries that were pioneers in defining the concept at the end of the $20^{\text {th }}$ century. Martin ${ }^{2}$ and Owen (2010, 211-224), for example, suggest that it has, in terms of being an explicit concept driving security, dropped off the political agenda, and that principle proponents, or first generation advocates (FGAs) of human security (Canada, UN) as they put it, are 'going through a period of withdrawal from both the advocacy and use of the concept' (Ibid, 211). Whilst they posit that this raises important questions about the failure of human security to establish itself as a concept and 'new' policy paradigm (in terms of FGAs), they also argue that there is an emerging second generation of advocates (SGAs), driven by the EU, and to some extent the United States (US) in its new thinking on security that focuses on the 'population' (population-centred security) (see Kaldor and Beebe 2010).

Their analysis then, raises questions of how human security is understood within the EU dimension, how and in what ways the human security narrative has evolved and been diffused within the EU, and finally, and most importantly, the extent to which human security in the EU is actually emerging or, similar to FGAs, has rather dissipated in its importance with regard to its significance as a strategic narrative driving the EU's security agenda. Their assumption is that the EU can avoid the pitfalls of the UN narrative if a clearer articulation is provided in terms of the concept and its use in political and practical policy terms (Martin and Owen, 221). They further assume that there is a desire and the political will to elevate human security to the strategic level - as a driver for its evolving security policy in the post-Lisbon era. 
Whilst there is much to commend about their analysis and argument, the suggestion here is that even within SGAs such as the EU, human security as a strategic narrative and leit motif is not explicitly discussed or indeed entertained as a driver for the EU's security actions. It is argued that whilst EU practice across various dimensions of its policy: development, peace-building, humanitarian aid and assistance, conflict resolution, crisis management, human rights, etc, is reflective of the principles that underpin human security in a broad (freedom from fear and freedom from want) and narrow sense (R2P), human security as a strategic narrative has not been embedded across the EU's institutional 'security' architecture. Moreover, it seems that the concept of human security, despite attempts at conceptual and policy clarification from the advocacy community, is still perceived as too ambiguous for it to be elevated to the dizzy heights of strategic narrative, even though there does not exist any identifiable opposition in principle, and precisely because there is a feeling in practice that the EU is already doing human security by another name. This article will suggest that such a narrative has not evolved as a driving concept despite its explicit inclusion in the Report on the Implementation of the European Security Strategy (2008), and that there exists little interest in political terms for pursuing a human security narrative as an underlying construct for the EU's security identity. This is not to posit a normative argument about what is most appropriate as a strategic narrative for the EU's security policy; in the current global milieu the EU's strength, quite ironically, lies precisely in the human dimensions of its security (Boonstra 2012). Unfortunately, the prevailing economic and financial crisis has created an environment whereby member states cannot think strategically or holistically about 
the short or medium term future of the EU; whether this is connected to its internal integration project or indeed a strategic frame for guiding its security actions ${ }^{3}$.

This article will first and foremost set out to provide an understanding of how and where the EU's human security narrative has evolved for the purpose of identifying the key debates on the concept and discussing the possible reasons for the failure of the concept to resonate or embed itself into the EU's grand 'security' narrative, in any strategic way. Methodologically, it draws on evidence collected through analysis of EU primary documentation, as well that of other relevant international organisations, countries and advocacy groups, and secondary sources on the EU and human security and human security more generally. It also draws on scoping and more substantive interviews conducted with officials at different levels and within different institutions of the EU (EEAS, Council, Commission, and European Parliament) as well as organisations such as the UNDP and the Food and Agricultural Organization (FAO).

The article is structured as follows in order to articulate its argument. Section one will briefly outline the context in which the issue of human security appeared on the EU agenda. Section two will then analyse how the human security narrative has evolved and been understood within the EU milieu and assess how such a narrative resonates across the EU. The final concluding section, will offer some reflection on whether we can locate human security as a core narrative in the EU today and its potential to embed itself more strategically in the future. 


\section{The European Union and Human Security}

The European Union's interest in human security as a potential guiding 'strategic' concept can be located in the shifts that have taken place in the international order, and specific events that have meant a recalibration of the referent of security from the state to the individual in the face of 'new' security challenges. It must also be understood in the context of the evolution of the EU's foreign and security identity, in particular since the 1998 St Malo agreement between Tony Blair and Jacques Chirac, which created real momentum in the creation of EU 'forces for action', military and civilian.

Externally, whilst in the bipolar Cold war period the state was seen as the main provider of security, a shift to a multipolar world order and the increasing role of non-state actors (as threats as well as agents of security), alongside the wars in the Balkans and Kosovo, and 'new wars' more broadly, led global and regional actors to ask the question of where the sovereignty of the state ended and where the international obligation to defend human rights and avert humanitarian disaster started. The process of globalisation (de-territorialisation, growing interdependence and interconnectedness across different dimensions, and the erosion of state autonomy) also blurred the lines between internal and external threats, and brought into question the relationship between security of the state and security of the individual (Glasius and Kaldor 2006, 6). The events of 11 September 2001 and subsequent terrorist attacks in Madrid (11 March 2004) and London (7 July 2007) also called into question the nature of the threat 'out there' - and made it clear that 'insecurity' and 'instability' was borderless needing an approach that was focused 
more on the individual, and that was comprehensive, rather than more traditional defence-oriented.

The EU, in this context, and in particular Javier Solana, having taken up the post of HR in 1999, was keen to construct a global role for the EU that was differentiated from that of the traditional - that is - state-driven approach that focused on securing the border. Indeed his interest was in creating an alternative to the US unilateral approach (Bush doctrine) through embracing a broader notion of security embedded in the process of multilateralism (Kaldor 2010). The European Security Strategy (2003) was reflective of the changing security context and recognised the nature of the new threats within it, outlining five key threats to Europe: terrorism, the proliferation of weapons of mass destruction, regional conflicts, failing states and organised crime. The ESS also recognised that such threats were global and not simply European, and that political insecurity in different parts of the neighbourhood and beyond - whether caused by failed states or non-sates actors needed a 'people' first approach - military power in its traditional form and use only exacerbated problems on the ground, and at worst was largely ineffective in the face of the new threats and challenges (suicide bombers etc). Given this changing and dynamic security milieu Solana was keen to emphasise that a 'military response is not enough to deal with the new threats and challenges faced by the international community', and that indeed, new threats to Europe and the EU, needed a 'comprehensive approach...[and a]...military-civilian balance (Ibid). Moreover, he asserted that 'in a globalised world, our security and prosperity depend on an effective multilateral system, with well-functioning international institutions and a rule-based international order' (Solana 2004). So although human security was not spoken explicitly at this early stage and indeed the ESS did not 
include the concept in its pages, the principles that underpinned it were very much in the mind of the EU's HR.

Indeed, it was Javier Solana, following the war in Iraq, and the internal European disagreements on this, as well as the formulation and agreement on the EU's first ESS that requested a Study Group on European Security Capabilities be convened (funded independently of the EU). The terms of reference for the Group agreed with Solana were twofold: first, that it should concentrate on defining, in a pragmatic way, how the ESS could be implemented; that is, on what capabilities were needed; second, that instead of focusing on a top-down, hierarchical solution to security, it should focus on bottom-up approaches that address security concerns of individuals in Europe through appropriate action to solve security problems on the ground (A Human Security Doctrine for Europe, 2004; Glasius and Kaldor 2004, p.xiv). It is also important to note at this point that the emphasis of the Barcelona Report (discussed in more detail below in terms of content) was quite narrow in terms of discussing 'human security' in the broader context. It focused on 'freedom from fear' and situations of severe physical insecurity, rather than the broader definition incorporating 'freedom from want' that was produced by the United Nations Human Development report in 1994 (UNDPHDR).

Beyond the political context, the conceptual context is also important for understanding how the Study Group on Human Security (SGHS) subsequently elaborated on the original Barcelona Report on HS, and how the EU, at least in the narrative of its major proponents, subsequently came to define HS. Moreover, it also provides a basis for explaining the diffusion of such a concept with the EU or lack of it in terms of its adaptation as a strategic narrative. Whilst we can trace the original human security agenda back to the 1948 UN Declaration of Human 
Rights with its emphasis on universal and individual rights (Kotsopoulos 2006, 6), it was not until the 1994 UNDPHDR that such a concept was made explicit in the lexicon of the UN and subsequently become widespread in the security narratives of governments, NGO's and academics alike (Glasius 2008; McFarlane and Khong ${ }^{4}$ - again, with the trigger being the changing nature of security and the need for a review of the main referent for such security and thus the tools through which it could be achieved (away from state and territory, to the individual, and development to combat insecurity). It was only at this stage that HS was elevated to the level of doctrine - with the definition and intent deliberately broad in order 'to bridge freedom from fear - indicating freedom from violence - and freedom from want - related to poverty alleviation' (UNDP-UNU-CRIS, 2009, 7). This definition incorporated different dimensions of human security - economic, food, health, personal, environment, political, community - and was characterised by: universality (relevant to all people everywhere), Interdependence (all dimensions mutually reinforcing), Prevention (rather than reaction) and People/Individual centred (how people live and exercise their options in any given society) (UNDPHDR, 1994). Of course such a broad definition of HS, as revolutionary as it might have been relative to traditional views, meant that debates ensued on how it could be used in a meaningful and practical way. Such a debate played out among leader countries - such as Canada, Norway and Japan- but also within academic circles. The Canadian (and Norwegian) approach to HS has been representative of a narrow definition which largely restricts itself to 'freedom from fear' - that is, violent threats against the individual. Indeed, it has argued, that the narrower focus, which decouples it from the field of development, allows HS as a concept to be operationalised through a focus on the 'more immediate necessity for intervention 
capability' (Liotta and Owen, 2006, p.43). The Japanese approach has been more aligned with that of the UNDP, in that it has focused on protecting the 'vital core' (i.e. the seven dimensions of the UNDP report) and emphasised the importance of development and human dignity. Academic debates on HS have evolved along such lines as well - narrow Vs broad, idealistic Vs pragmatic, with academics (and various IOs) providing a wide array of definitions and placing different weight on the dimensions of HS (Liotta and Owen, 2006, p.50). Others have sought to critique the concept of HS from a critical theoretical perspective, discussing HS as an excuse for neo-imperialist or Western (nefarious state) intervention; or deconstructing what is seen as the myth of human security in relation to its representation as a paradigmatic shift (Glasius 2008) from state to individual security (Chandler 2008) ${ }^{5}$. Others still have argued that it is simply a label for what is already being done under other names and thus adds no value (Matlary 2008); and that, HS does not have definite parameters and that the ambiguity of the concept makes causal links difficult to establish analytically (Paris, 2004, 2001; Liotta and Owen 2006). Indeed certain scholars have proposed that we need to define more precisely, what intervention means under a HS approach (i.e. what is the 'threshold' for intervention), so that the concept becomes much clearer for operational purposes and everything does not simply become 'security' (Martin and Owen 2010).

The point of this brief overview is that despite attempts to define HS and make it workable or operational, the very nature of the concept - in particular its 'broad' variety - invites much scepticism in terms of how it can be (and whether it should be) theorised and used strategically in policy-making circles. Such ongoing debates, of course, have resonance for the EU and indeed the aims of the article in 
understanding how the concept has evolved in the EU's narrative and how it has played out at the strategic level and the level of everyday actions and practice. The next section turns its attention to this very issue.

\section{A Genealogy of EU Human Security Narratives}

The EU has, over the years, developed policies that have sort to protect and provide security to individuals and communities within its borders (UNDP-UNU-CRIS, 2009), even though the current climate created by the financial crisis has brought to the fore many 'insecurities', political, economic and social, and in particular amongst southern Member States. Despite the salience of the events inside in terms of the questions it raises over human security within the EU's borders, the focus in this article is on the EU's external relations and human security. Indeed, it is on how the concept has evolved in the context of the EU's projections outside, as a foreign and security policy actor ${ }^{6}$.

As alluded to above, countries within Europe (EU members include Austria, Greece and Ireland) have been active trans-nationally through the Human Security Network, in promoting the concept of human security, even though it has been argued more recently that the Network has become increasingly marginalized (Martin and Owen 2010, p.211). In terms of the EU's shift towards narratives of human security, however, it is the work of the study group and their proposals in the Barcelona Report (A Human Security Doctrine for Europe, 2004) that really planted the seeds with regard to how human security could provide the strategic narrative for implementing the ESS. That is, on how the human security narrative could become an 'institutionalized' strategic way of thinking - a doctrine - for the 
EU's external relations. In arguing that EU security state should base its policies on human security rather than state security, the Report outlined three reasons for why it should do so: a) Morality - that is, because all human life is equal and all humans have the right to live securely and with dignity (as a universal norm not simply European); b) Legal - given that human security and human rights are different parts of the same spectrum, and that there is a general or universal acceptance to promote and protect the latter embedded in the United Nations Charter and other HR treaties and documents that the EU is signed up to, then the EU is obliged to concern itself with human security. In addition the HRSG group point out that there is recognition of its obligation to human security within the (now defunct) Constitution in terms of a commitment to peace, security, sustainable development, and protection of human rights, etc (still present in the Lisbon Treaty that was eventually agreed); c) finally, enlightened self-interest, which links closely to a) and b) and makes the point that in a world characterised by porous borders the EU's interests (that is security needs) can only really ever be met by addressing the insecurities (and instability) around the world.

Table 2 Principles for the EU Human Security approach $^{7}$

\begin{tabular}{|c|l|l|}
\hline 1. The Primacy of Human Rights & $\begin{array}{l}\text { Which distinguishes the HS approach from } \\
\text { state-based approaches and implies that those } \\
\text { that violate HR be treated as individual } \\
\text { criminals not simply collective enemies }\end{array}$ \\
\hline 2. Clear Political Authority & $\begin{array}{l}\text { Refers to establishing legitimate political } \\
\text { authority that can uphold HS on the basis of } \\
\text { local consent and support. }\end{array}$ \\
\hline 3. Multilateralism & $\begin{array}{l}\text { Broadly understood (not simply cooperation } \\
\text { between states) and with three aspects: } 1 . \\
\text { commitment to work within IO's and their } \\
\text { procedures; } 2 \text { Commitment to working within } \\
\text { agreed rules and norms in terms of cooperation } \\
\text { and enforcement; 3. Coordination rather than } \\
\text { duplication or rivalry internally and with other } \\
\text { international actors (coherence) }\end{array}$ \\
\hline 4. A bottom-up approach & \begin{tabular}{l} 
Where policies are reflective of the basic needs \\
\hline
\end{tabular}
\end{tabular}




\begin{tabular}{|c|l|}
\hline & $\begin{array}{l}\text { identified by the vulnerable and insecure they } \\
\text { seek to help }\end{array}$ \\
\hline 5. A Regional focus & $\begin{array}{l}\text { Stemming from the fact that conflict and new } \\
\text { wars do not have clear boundaries/national } \\
\text { borders. Solution should therefore have a } \\
\text { regional focus to allow practices to spread } \\
\text { between localities }\end{array}$ \\
\hline 6. Use of legal instruments & $\begin{array}{l}\text { The use of law not just in terms of intervention } \\
\text { but at operational level, at societal/citizen level } \\
\text { (involvement in administration of justice) and } \\
\text { with regard to bringing terrorists, criminals to } \\
\text { justice through legal procedures }\end{array}$ \\
\hline 7. Appropriate use of force & $\begin{array}{l}\text { That is intervention should be in line with } 1 . \\
\text { and 6. with minimum force and necessity key. }\end{array}$ \\
\hline
\end{tabular}

The human security narrative suggested by the HSSG then was underpinned by a strong normative steer, and alongside this, the suggestion of core principles (see below) and mechanisms to implement a human security doctrine. The mechanisms for implementation were also ambitious and innovative, with implementation to be 'done in a holistic way...[and where]...civil-military integration applies at planning level as well as operational level' (A Human Security Doctrine for Europe, Barcelona Report, 2004, p.18). The Report suggested the formation of a 15, 000 strong human security response force (the professional core), 5000 personnel of which would 'be on permanent standby constantly training and exercising together and 'breathing human security'...and able, at short notice, to deploy 'Human Security Task Forces" (HSTF). The remaining 10, 000 personnel would only periodically train together, would be at lower levels of readiness, but nevertheless deployable. In addition to this was a proposal for a voluntary core, to contribute to the HSTF (Ibid, p.19).

The HSSG however, whilst endorsing the broad conceptualisation of the UNDPHDR (1994) and the subsequent Human Security Now report (2001) produced by the Commission on Human Security (formed 2001) which emphasised that the aim of HS was 'to protect the vital core of all human lives in ways that 
enhance human freedoms and human fulfilment', did not 'prescribe such a mandate' (Martin and Owen 2010, p214). Instead, and with the justification of making the concept workable and operational, there was a narrower focus on the 'depth of threat' and the 'the needs of people in severe security' (Glasius and Kaldor 2005, 67; see also Glasius and Kaldor 2006).

Such proposals, however, did not find enough resonance in and across the EU institutional milieu for them to be adopted as strategic concept or indeed policy, even though the evolution of ESDP continued in terms of the military and civilian dimensions. This is not to say that key individuals such as Ferrero-Waldner and Solana did not advocate the notion, even if tentatively for the latter - and more broadly for the former. Indeed, in a speech given in 2006 on the EU's approach to democracy promotion, Ferrero-Waldner made quite clear that 'Central to the EU's approach is the concept of human security - an idea of security which places people at the heart of our policies. It means looking at the comprehensive security of people, not the security of states, encompassing both freedom from fear and freedom from want ${ }^{\prime 8}$. Interesting here then, is that whilst Ferrero-Waldner clearly took on and communicated the narrative in the Barcelona Report, she steered away from the narrower approach advocated by the report, in favour of also emphasising the freedom from want as an important dimension of the EU people-centred approach. With Solana, in his speech assessing the progress of the ESS and the EU's foreign policy more broadly in January 2005, he asserted that 'The notion of human security - which puts the security of individuals front and centre - is fast gaining ground, and rightly so...' (Solana 2005), whilst acknowledging that much work still had to be done in terms of human security on issues such as 'disaster relief, civil protection, and...civilian crisis management' (Ibid). The message that 
penetrated then, at least within elite level discourse among the main advocates, was that if the EU was going to meet the security challenges and address the security problems of the $21^{\text {st }}$ century, security and development had to be further reconciled, and the key principles of human security, also present in the ESS, had to become more of a reality (multilateralism, coherence, etc). What was also clear though, was that not all elements of the Barcelona 'doctrine' for the EU were communicated and diffused internally or projected externally as a strategic narrative for EU foreign and security policy.

Whilst many member states in the Council, as well as officials in various DGs (Interviews, EEAS and European Commission, January 2012) remained sceptical of the concept and critical in that is was seen as ambiguous, unclear, soft and a label for existing practice, others did not. Finland, keen to take the human security agenda forward, used its Presidency of the EU (June-December 2006) to request that the HSSG was reconvened and 'continued bilaterally to press for a more explicit normative focus within the ESDP and for the EU to implement commitments on human rights and gender'. Finland pushed human security within the EU institutional milieu (PSC in particular) and was also at the forefront of piloting more pragmatic measures reflective of the human security approach; namely through HS training for ESDP military and security personnel(Martin and Owen 2010, p218) ${ }^{9}$. When reconvened by Mary Kaldor the HSSG was commissioned to examine how to take forward and examine the human security agenda which was set out in the Barcelona Report of 2004. The experts brought together to do this represented an epistemic community of people that had been involved in 'security' - practitioners, policy-makers and academics. In essence the Madrid Report which followed from this in 2007 entitled A European Way of 
Security, was an attempt to add depth to the concept of HS in conceptual and pragmatic, institutional terms for the purpose of embedding it as a strategic narrative within the ESDP. Indeed one of the dimensions focused upon was case studies of ESDP missions to illustrate exactly what a HS approach would look like on the ground (Martin and Kaldor 2010). It was also, however, an opportunity to address two sets of critiques that had emerged from policy-makers and other commentators on the concept of HS: a) That it was a cloak for a new European militarism/neo-imperialist/neoliberal intervention; b) That it was too soft a concept and too ambitious, thus not that relevant to the EU (A European Way of Security 2007).

It addition it reiterated the same principles of the human security approach - with one difference - the use of legal instruments and the appropriate use of force were subsumed into the other five principles - and a sixth principle was added - of "clear and transparent strategic direction', which basically stated that 'When the EU intervenes externally it must do so with clear legal authorisation, transparent mandates, and a coherent overall strategy. Where European security units are deployed there should be close linkage between policy makers and those on the ground, with the former having ultimate control over operations. All EU external engagements should be led by civilians' (Ibid, p.10, my emphasis).

I emphasise this final point because this narrative was not one which resonated well with Solana, even though the rationale for this was that it was 'the best way to achieve improved planning and post-conflict reconstruction' (Solana and Kaldor 2007). He questioned that a civilian lead should be obligatory for all EU operations, and argued that military personnel could, in certain situations, be better suited to leading, fulfilling and implementing a HS agenda, in particular given the mixed 
nature of EU operations on the ground. In Solana's opinion, the context in which the EU's civil and military operations were framed was so ambiguous that it required a flexible approach, so that 'neither solely theoretical approaches nor purely practical ones can be employed to create a perfect model that can be implemented successfully'. Solana also claimed that any model should be able to move 'from theory to practice and from practice to theory' (Ibid). So Solana, whilst clearly committed to a human security agenda did not necessarily concur wholeheartedly with the prescriptions of the Madrid Report, even though it emphasised that 'A European Way of Security must be a hard security policy, which involves the use of military force' (A European Way of Security, 2007, p.10). For the HSSG, however, and importantly for their vision of HS, military force would operate under civilian command, and would be used 'to protect individuals, to create the basis for a rule of law, and to arrest those who violate the law' (Ibid). Importantly, they argued that if the EU was to adapt HS as a strategic narrative, it had to be done under specific conditions to avoid any criticism of neo-imperialist ambitions, but also to differentiate the HS approach from the traditional state (military led) approach which focused on defeating the enemy (or the peacekeeping approach which focused on separating conflict parties).

In response to the criticism from academics and policy-makers alike about the concept of human security being soft, fuzzy and ambitious, the Madrid Report acknowledged that 'Human Security encompasses many of the concepts used by the EU in its missions' (Ibid), but argued that it took concepts such as crisis management, conflict prevention and civil-military cooperation further. For example: crisis management was seen as much more than securing stability; it was about the security of individuals and communities - 'how to deal with violent 
organised crime, widespread human rights violation, or joblessness...'(ibid); conflict prevention, where key aspects already resonate with a HS approach, should not simply be seen in terms of phased intervention but more holistically in terms of addressing crises and the vulnerabilities that stem from these across space and time in conflicts; and finally, civil-military cooperation, where a HS approach is about 'how and why civil and military capabilities are combined, rather than a reflex action to use them as part of the standard conflict toolkit'(Ibid, p.11). The central point made by the Madrid Report then is that 'a clear concept such as Human Security would allow the EU to refine and coordinate what it already does under multiple labels', making more sense of what was already being done but potentially increasing the EU's coherence, effectiveness and visibility in terms of security policy. In this sense it is not too ambitious or indeed utopian, but more realistic, although it is acknowledged that the main challenge for achieving it would be 'cognitive as much as practical' (Ibid).

So how far was this cognitive change in thinking visible in the EU's elite narrative after the publication of the Barcelona and Madrid Reports, and importantly, which aspects of the Reports were embraced and internalised (and where)?

\section{Diffusion of the Human Security Narrative: Where are we now?}

The many advocates of the HS approach, even though cautiously, point to the 'Report on the Implementation of the European Security Strategy' (2008) as evidence of the EU's acceptance and internalisation of the concept. It elaborated on a 'distinctive European approach to foreign and security policy', and demonstrated explicitly, for the first time, its commitment to HS, stating that, 'We have worked to build human security, by reducing poverty and inequality, promoting good 
governance and human rights, assisting development, and addressing the root causes of conflict and insecurity'(Ibid, p.2). It further highlighted the need 'to continue mainstreaming human rights issues in our activities...including ESDP missions, through a people-based approach consistent with the concept of human security' (Ibid, p.10). Whilst human security was attached to the strategic goals of the EU in this document, however, the significance of its inclusion (only twice mentioned) has not been overstated. Indeed, there has been some recognition that human security as a concept was rather secondary to that of effective multilateralism which featured heavily in the original ESS in 2003 as the most central pillar of the EU's foreign and security policy (Martin and Owen 2010, p217). Some academics have suggested that its inclusion was simply an example of 'fetishizing' the textual record of the ESDP (Chandler 2008), although others clearly believe that its inclusion is more than just a 'fetish' - indeed, whilst not indicating a formal paradigmatic shift in security thinking, they point out that it at least embraced and drew upon in a more obvious and detailed way the central themes and underlying principles of human security, not just in relation to human rights but also gender, poverty, and a people-centred approach. Furthermore, they point out that such progress was particularly important in the 'institutional context of the EU and in particular the Council, given their original reluctance to entertain the concept after 2003 after Member State disagreements over Iraq (Martin and Owen 2010, p217).

Even if we accept the Implementation Report as incremental, evolutionary progress in changing the thinking on HS, however, it does not seem that it was presented or indeed intended as a core or strategic narrative that could or should frame the EU's security policy. Subsequent Council Conclusions, in particular in the post-Solana 
era, have not elaborated on the concept of HS as core narrative (Council Conclusions on Conflict Prevention, 2011), even though Solana has continued advocating the concept as an approach, through, for example, initiating the project that led to the formation of the EU-Russia HSSG, which Solana was also a member of (see Helsinki Plus Report 2010). Indeed in the EU's priorities for the $66^{\text {th }}$ Session of the United Nations (EU Priorities for the General Assembly, June 2011), only a procedural point was added on the issue of HS demonstrating that the concept was 'low level', that it still generated some scepticism as to what it added to the EU's practice (Interview, EEAS, November 2011), and indeed what it meant in terms of operationalisation:

The EU will continue to promote the concept of Human Security as a comprehensive, integrated and people centred approach in addressing interrelated threats to security, livelihood and dignity of people and vulnerable communities. Further reflection is needed to identify the thematic areas in which this approach can best show its added value and concrete applications to achieve this objective (EU Priorities for the General Assembly, June 2011)

This suggests that whilst HS as a concept is important, there is clearly difficulty in the EU in conceiving it as a core/holistic narrative. Rather, many, in the Council at least, believe that 'there is not just one discourse on HS but several' across the EU (Interview, EEAS, November 2011). There was also the issue of the political visibility of the concept, where 'there was a lack of conviction among Member States' on the utility of HS as a strategic narrative. This was not because HS per se was not being done, just that the concept was not necessarily perceived as helpful as a 'brand' or 'label'. Indeed, narrower concepts such as the Responsibility to 
Protect (R2P) were clearly important and prominent in discussions, but it was not necessarily or explicitly linked to the broader concept of HS - which is still seen as more 'abstract' (ibid). From a Council perspective R2P is a clearer, narrower and much more operationisable concept that can bring added value to the EU's actions. The EU has, therefore, in contrast to HS, committed to striving:

...for the operationalization of the concept of Responsibility to Protect (R2P) on the basis that the concept is not open for renegotiation. The EU will apply a "narrow but deep approach" to R2P-related policies and will particularly focus on its preventive pillar. The EU welcomes the reference to this concept in UNSC Resolutions1970, 1973 and 1975 (EU Priorities for the General Assembly, June 2011).

In terms of the EEAS it is difficult to define any sort of narrative on human security, but again, whilst there are many references to human rights and development, and a comprehensive approach for CSDP in Catherine Ashton's speeches since taking office (see, example Ashton 2011a and 2011b), there is little evidence that human security as a brand or strategic concept has been given high priority. As one EEAS official pointed out to the author, 'human security is not a sexy topic any more' - it is not high on the in EU's political agenda (Informal discussion, EEAS, May 2012). It seems unlikely given the low salience of HS on the political radar, and the fact that the EEAS is preoccupied with getting its institutional design right in the coming years that the HS as a core narrative will feature in the EU's security thinking, even though it is prominent in its everyday practice. 
The European Parliament (EP) - or, again - certain parties within the Parliament have supported the idea of a shift to human security as a core narrative for the EU's ESS. The Report on the European Security Strategy by the EP in 2005 certainly made explicit reference to inclusion of the ideas in the Barcelona Report welcoming, 'developments in the field of ESDP, such as the establishment of Civ/Mil [civilian-military cell], which are in congruence with the general direction of this report, but also the future creation of a European Voluntary Humanitarian Aid Corps'(European Parliament, March 2005). In terms of the latter it demanded that this be 'expanded or complemented by the creation of a complementary "Corps" so as to draw upon the experience and expertise of mid- and post-career professionals in attaining a functional corps more along the lines of the European Civil Peace Corps', as the European Voluntary Humanitarian Aid Corps is primarily envisaged as "a framework for joint contributions from young Europeans"' (Ibid). In other words, the EP proposed it should be brought more into line with the recommendations in the Barcelona Report that saw the establishment of a 5000 strong voluntary human security force.

Another example of EP support for HS as guiding doctrine for EU security policy was the amendment proposed by the Parliament to the Committee of Foreign Affairs' Kuhne report on the Implementation of the ESS Kuhne Report, 15 May 2008). The Parliament proposed an amendment to include 'an emphasis on the concept of HS with the objective of initiating 'a robust political mandate enabling it to act effectively in crises' (Martin and Owen 2010, p218). This proposed amendment was narrowly rejected - by twelve votes - due to blocking motions by opposition parties (Ibid). 
Whilst this certainly demonstrated, at least for proponents of the HS as core narrative that progress was being made, the consequence and indeed reality seems to be that it has remained marginalized as a strategic narrative and holistic frame for the EU's security policy. Within the EP, HS has been internalised as part of what is done in the relevant committees (Development, Foreign Affairs \& subcommittee on HR), but without explicit reference to the label of HS - even though much discussion is invoked in the language of human rights, development and democracy assistance. Indeed, issues such as food security or human rights are frequently discussed and are on the agenda in EP meetings with third parties at different levels (Interview, European Parliament, Nov 2011), but there does not seem to have been a paradigmatic shift towards HS as an overarching frame for how the EU does security. The lack of reference to HS is also evident in the EPs recommendations to the Council with regard to its activities in the UN, even though what are conceived of as aspects of a HS approach, such as advancing effective multilateralism and mainstreaming and advancing gender equality (European Parliament Report, 13 May 2011), are clearly prominent.

Although many member states remain sceptical of the concept of HS as core narrative $^{10}$ the Commission, or at least certain elites within the Commission, have been the most explicit in promoting human security as a holistic concept for the EU's security policy. Most vociferous in the campaign before stepping down as Commissioner for External Relations and European Neighbourhood Policy in 2009, was Benita Ferrero-Waldner. Her motivation to push the concept within the EU stemmed from her interest and involvement with it in the time as Austrian foreign minister, where she also chaired the Human Security Network (HSN) in 2002-3 which Austria was very much involved in founding alongside Norway and 
Switzerland. Richard Kuehnel, who became Waldner's advisor in the Commission on Human Security, had also been involved as coordinator of the HSN in New York at the same time. When Ferroro-Waldner took up her position, 'the concept of human security was on the fringes of the debate, even in the Commission'(Telephone Interview, February 2012). Her projection of the concept of HS, at least publicly, was based on a broad definition - and included freedom from want and freedom from fear, as well as the ability to express oneself on one's behalf - explaining in 2006 that, 'The philosophy underlying the EU's approach to security, as outlined in the Security Strategy, is that security can best be attained through development, and development through security. Neither is possible without an adequate level of the other. That's why we focus on the holistic concept of human security' (Ferrero-Waldner 2006). However, there was also recognition that this was very broad 'and the idea was to narrow it down to more imminent threats and not the whole climate change and what have you debate' (Telephone Interview, February 2012). In essence the approach taken by Ferrero-Waldner, was on the one hand to contribute to the definitional debates on human security, but whilst this went on, 'to put concrete action on the ground, to be pragmatic and to look at concrete targets and to focus on specific results under this policy' (Ibid).

In this sense the approach advocated and taken by Ferrero-Waldner sat somewhere in between the broad and narrow definition of human security provided by the UN/Japan and Canada respectively (Ibid), with the practice of HS clearly evident in informing policies on armed conflicts, small arms and light weapons, nonproliferation, mine action and human trafficking; with the recognition that its use was often 'synonymous with initiatives on human rights' (Martin and Owen 2010, p.218). Indeed, Martin and Owen (2010, p.219) argue that the Commission 'located 
it [HS] differently from the that of the UN', in that it sat within a crisis management and conflict resolution frame and included material security as well as physical protection'. The politicisation of the concept through Ferrero-Waldner meant that human security also penetrated, or found expression, in different ways not just as a means of addressing insecurity and underdevelopment, but as a concept that would integrate often competing HS agendas within the EU, leading to better coordination and cooperation internally and on the ground. Indeed certain commentators argue that, 'So far, the EU has successfully positioned the concept as a viable strategic narrative for a supranational foreign policy: it has influential sponsors and is widely, if not unanimously, accepted across the membership' (Ibid, p.220). Whilst they also recognise that it is one thing to gain institutional recognition and another thing to argue that this represents any embedded or normative shift, they assume that as long as the EU avoids the mistakes of the UN and provides 'clear conceptualization' and 'clarity of intent', transformation is achievable.

Whilst for sure there is was a pressure to develop a strategic narrative to guide European security policy, even more so given developments in CSDP (postLisbon), and changes in the global order, the questions that remain unanswered are the extent to which such a singular understanding, conception and narrative of HS existed and exists within the Commission - across the relevant DGs involved in 'human security' and whether HS is indeed considered as the answer - as the missing grand strategy that can provide a rationale and coherence for the EU's security and foreign policy activities. Such a narrative was clearly projected under Ferrero-Waldner, but it is less clear who has taken up the mantle since her 
departure in the Commission (as well as that of Solana) and how far down (in the Commission) or indeed across the EU institutional milieu it penetrated.

Certainly at working levels, in Directorate Generals such as Development (and Cooperation) and Humanitarian Aid and Civil Protection (DG ECHO), the concept of human security has not resonated, 'it is not used discursively' (Interview, DG ECHO, November 2011). Indeed certain officials involved at the operational level in DG ECHO argue that they do not talk about human security but rather 'resilience' ${ }^{11}$; they work not on preventative intervention (that is the job of DG Development) but rather proactive intervention in vulnerable humanitarian spaces. Others have argued that human security as a concept was a top-down driven process and that the language of human security fell off the agenda when FerreroWaldner and Solana left office (Interview, DG ECHO, January 2012). What was a common theme in all interviews in the relevant Commission DGs was that the 'brand' as strategic narrative had not penetrated, and in some cases the interpretation of human security led to the conclusion that 'human security' was not being done. At the extreme end of the spectrum there were those working on peacebuilding and conflict prevention that were not even aware of the work undertaken on the concept by the HSSG (Interview, DG DevCo, January 2012). Even in the quite specific area of 'food security', the human security label was not credible as 'The risk is having a concept so broad that you can include in this concept everything - and everything means nothing at the end of the day' (Interview, DG ECHO, Food Security, January 2012).

At the elite level there is evidence to suggest, certainly from the available public documents and speeches among the relevant Commissioners, that HS as strategic narrative has not been taken forward or been as vigorously 'marketed' as it was 
before 2009/10. A speech by Andris Piebalgs, Commissioner for Development, on the future of development policy and its challenges (Pielbags, 2011), provides a good example of how the HS label has dropped off the 'public' diplomacy of the EU. The key challenges are identified under the themes of Governance, Inclusive and Sustainable Growth and Delivery and Results on the ground. Human security does not appear once in the document, even though, many of the themes common to a HS agenda are iterated throughout: reducing poverty, empowering women, and local actions and involvement.

It is a similar story if we analyse the speeches of Kristalina Georgieva, Commissioner for International Cooperation, Humanitarian Aid and Crisis Response. In a speech on 'Policy Priorities - Achieving and mapping the way ahead' (Georgieva 2011a) there is no mention of human security as an approach or frame, but there is an emphasis on coherence (internal and external), a comprehensive approach covering response but also disaster preparedness and prevention, as well as working more effectively with (in) the international humanitarian system. Importantly, Georgieva talks of the launch of the EVHVC, which whilst certainly not going as far as the Barcelona and Madrid Report recommendations, taps into the HS rationale for their presence in helping victims of conflict and natural disasters. Finally, in relation to the final key priority outlined in the speech, the label food assistance policy is preferred over food security policy, even though the two are subsequently used synonymously in the following sentence. Similarly, in a speech on the challenges for humanitarian action (Georgieva, 2011b), it is interesting to note that the main guiding principles for action are drawn from International Humanitarian Law (IHL), and internally, on the European Consensus on Humanitarian Aid and the Lisbon Treaty chapter on 
humanitarian aid. Also prominent is the language of effectiveness, efficiency, partnership and synergy (between humanitarian aid and development). The use of the military is also condoned, but within 'well-defined conditions which respect the humanitarian mandate and international norms' (such as the Oslo accords and the MCDA guidelines) (Georgieva, 2011b).

The common theme that emerges from analysing elite speeches then is that HS as a doctrine or strategic narrative is clearly not promoted or spoken - at least in relation to the DGs that historically, and in the contemporary context, have been at the forefront of doing human security. Of course the institutional milieu is more complex now with DG RELEX subsumed into the EEAS and the latter still not fully constituted as yet, but it does seem that, within the Commission, and the expected key advocates, the thematic language and practice of $\mathrm{HS}$ - or at least many aspects of it - is more prominent than the label or brand as a core strategic narrative.

\section{Conclusion}

In providing a genealogy of EU narratives on $\mathrm{HS}$, the evidence seems to suggest certain trends across time, and with these, implications for the potential of HS to evolve as a strategic narrative that shapes and drives EU security policy.

The EU's adaptation of the narrative was driven, top-down, by key individuals within the context of a changing external and internal EU security order. We might even go as far as to say that Solana and Ferrero-Waldner were the key norm entrepreneurs that attempted to drive HS forward strategically, even though both did not necessarily conceive of the concept in exactly the same way in theory or indeed practice. Ferrero-Waldner, whilst clearly considering the definitional 
debates of importance, was primarily interested in how human security could be translated into concrete practice within the EU, and advocated an approach that sat between the broad and the narrow. Solana, although clearly investing much energy in promoting the HS agenda, did not see this agenda in the same way as the HS purists; indeed, in the EU context he believed there was a role for military as well as civilian personnel in implementing the concept. This, alongside the fact that there was little EU member state support, inevitably created a problem for sustaining the human security narrative across the EU's institutional milieu, and in particular between the Council and the Commission. It is difficult to sustain and indeed embed a narrative where no single or at least common narrative exists and there is no political desire to maintain momentum.

Advocacy groups such as the HSSG could be added to the list of norm entrepreneurs that were instrumental in projecting a HS narrative and frame for the EU's security policy. This was achieved primarily through the commissioning of the Barcelona and Madrid Report, with such advocacy continuing through the Civil Society and Human Security Research Unit at the LSE and initiatives such as the Helsinki Plus report which was initiated by Solana when he left office as EUHR. However, this group too had to adjust its definition and prescription of human security and once Solana and Ferrero-Waldner left office, the institutional dynamics within the EU, and in particular the lack of interest by the majority of EU member states to revive the debate, made it difficult to clearly push and articulate the concept inside and in particular how it could be used in political and practical policy terms.

Given that human security was introduced in a top-down way by key individuals that interpreted the concept very differently, it became difficult to define, diffuse or 
embed it across and within the EU institutional milieu in any equal or symmetric way. This difficulty was compounded by the fact that there was no single person that took up the leadership on this issue once those individuals left office. However, whilst it is not entirely clear how far down or across human security was diffused as a core strategic narrative the principles that underpin the approach and the main themes that characterise it are visible in the work done by the EU. Furthermore, at working level, discussions are mostly framed within the narrative of human rights, governance, resilience - the human security label is seen as 'too broad', 'unclear as to its added value in EU work'. In this sense it is still argued that human security is done in practice, but many officials do not see the point in pursuing or promoting a label that is still seen as too ambiguous. At elite level, human security does not appear in the public diplomacy of key Commissioners, and references to it in key EU documents (e.g. EU priorities at UN) demonstrate a low level of interest in it as an overarching frame for security policy. Responsibility to protect, on the other hand, is seen as a much narrower and indeed workable concept that can be operationalised more effectively, even though seemingly no less controversial.

The main implication, in opposition to those that believe adding clarity to the concept and practice will allow the EU as a second generation advocate to sustain the discourse is that the political will or leadership and drive to promote and diffuse human security as a core strategic narrative does not exist within the EU in the post-Solana and Ferrero-Waldner era. It might even be argued that whilst the changes in the Lisbon Treaty offered an opportunity to create a common narrative through creating a more coherent institutional structure through which to articulate and operationalise human security discourse and practice - it failed to do so. Indeed 
what we have instead is potentially a greater propensity for inter-institutional coordination challenges across the dispersed places within which human security is done in the EU and the different interpretations of the concept within and across these spaces - a challenge internally as well as externally in the EU's interaction with first generation human security advocates such as the United Nations, and critically, emerging powers that interpret human security through a state or sovereign based $\operatorname{logic}{ }^{12}$.

If one was more optimistic it might be argued that the rise of new regional and global powers in a dynamic multipolar world, alongside the potential for new norm entrepreneurs to emerge through the EU's institutional change of personnel in 2014 and the $20^{\text {th }}$ anniversary of the initial UNDP HDR (1994), could reinvigorate the debate on human security - and indeed the nature of the human security narrative in the $21^{\text {st }}$ Century. At present, however, it can only be concluded that the practices of the EU across the relevant institutional spaces are reflective of human security principles - but that the narrative has dissipated in its importance as a driving strategic concept. Whilst it might be argued that the devastating impact of the financial crisis in Europe and the worrying trends and consequences of climate change more broadly point to the limitations of national sovereignty and the outdated notions of territorial security thus an increasing relevance for the reintroduction of human security as a core framework, notions of state security among EU member states remain primary and critical in any EU CSDP. Indeed crisis in Europe has meant that member states have increasingly looked inward and reinforced a territorial approach - curtailing any hope that a holistic human security approach that puts the individual first, and that only allows military operations 
under civilian control, can emerge as a core narrative for EU CSDP in the near future.

\section{NOTES}

\footnotetext{
${ }^{1}$ The research for this article was funded by the large-scale integrated FP7 project, Global Reordering: Evolution of European Networks (GR: EEN). European Commission Project Number: 266809. I would like to extend a special thanks to Nicola Harrington-Buhay from the UNDP Office in Brussels for her invaluable assistance with this research. I would also like to thank Nicola and Antonio Vigilante (UNDP Office in Brussels), for taking the time to read and provide insightful comment on the first draft of the article.
}

${ }^{2}$ Mary Martin was the Coordinator of the Human Security Study Group - with Mary Kaldor Convenor and Sabine Selchow Assistant. They are all at the Centre for Global Governance, London School of Economics.

${ }^{3}$ An initiative led by Sweden, Poland, Italy and Spain produced a report suggesting new ways forward for the EU's security policy: ‘Towards a European Global Strategy: Securing European Influence in a Changing World' (2013).

${ }^{4}$ Although the term human security did appear in the works of certain academics in the 1990s: see Rothschild (1995) and Suhrke (1999)

${ }^{5}$ For a response to such a critique see Owen (2008)

${ }^{6}$ Although obviously it is difficult to separate inside and outside in reality; it can be argued that the financial crisis inside the EU, and its implications in terms of 'human security', is clearly a key factor influencing the extent to which the concept has fallen off the political agenda for Member States in its projection outside.

${ }^{7}$ A Human Security Doctrine for Europe, Barcelona Report, 2004

${ }^{8}$ Benita Ferrero-Waldner, 'Human Security and aid effectiveness: the EU's challenges', speech to Overseas Development Institute, London, 26 October 2006

9 See also:

http://www.intermin.fi/pelastus/cmc/home.nsf/pages/E57D63D16D771783C225795F002B38EB?op $\underline{\text { endocument }}$ 
${ }^{10}$ Note whilst not necessarily opposing different dimensions of it in practice that they conceive as workable, such as R2P (Interview, Council of Ministers, Oct 2011)

${ }^{11}$ See, also, for example: http://ec.europa.eu/echo/policies/resilience/resilience_en.htm

${ }^{12}$ See Breslin (2013) on China.

\section{Notes on Contributor}

George Christou is Associate Professor in European Politics, Department of Politics and International Studies, University of Warwick.

\section{References}

A European Way of Security, The Madrid Report of the Human Security Studies Group comprising a proposal and Background Report, , Madrid, $8^{\text {th }}$ November 2007

A Human Security Doctrine for Europe, Barcelona Report of the Study Group on Europe’s Security Capabilities, Barcelona, Spain, 2004

A Secure Europe in a Better World, European Security Strategy, Brussels, 12 December 2003. Available online at:

http://www.consilium.europa.eu/uedocs/cmsUpload/78367.pdf (accessed March 2013)

Ashton, C. (2011a), 'Common Security and Defence Policy', speech by High Representative Catherine Ashton to the European Parliament in Strasbourg, 13 December 2011, A 512/11, Brussels, 13 December 2011; 
Ashton, C. (2011b), 'The Annual Human Rights Report', Speech to the European Parliament, SPEECH/11/885, 13 December 2011

Beebe, S. D. and Kaldor, M. (2010) The Ultimate Weapon is No Weapon: human security and the new rules of war and peace. Public Affairs Books, New York, USA

Boonstra, J. (2012), 'What legacy for security and defence? in Ana Martiningui and Richard Youngs (eds) Challenges for European Foreign Policy in 2012. What kind of geo-economic Europe?, FRIDE, p. 44. Available online at:

http://www.fride.org/publication/971/challenges-for-european-foreign-policy-in2012.-what-kind-of-geo-economic-europe? (accessed February 2013)

Breslin, S. (forthcoming, 2014) 'Chinese Discourses of Human Security:

Discursive Power and Defining the Terms of the Debate', Journal of Contemporary Asia.

Chandler, D. (2008) 'Human Security: The Dog That Didn’t Bark', Security Dialogue, 39, 2008, p.427-438.

Council Conclusions on Conflict Prevention (2011), 3101 ${ }^{\text {st }}$ FOREIGN AFFAIRS COUNCIL meeting, Luxembourg, 20 June 2011 
European Parliament, 'Report: with a proposal for a European Parliament recommendation to the Council on the $66^{\text {th }}$ Session of the United Nations General Assembly' (2011/2030(INI), Committee on Foreign Affairs, 13 May 2011

European Parliament, 'Report on the European Security Strategy, European Parliament, Committee on Foreign Affairs', (2004/2167(INI)), FINAL A60072/2005, 23 March 2005

EU Priorities for the UN General Assembly, 66th General Assembly, 10 June 2011, Brussels - EU Priorities for the 66th Session of the General Assembly of the United Nations.

Available online at: http://www.eu-un.europa.eu/articles/articleslist_s110_en.htm (accessed February 2013)

Ferrero-Waldner, B. (2006) 'Protecting Europe's Security', speech to conference on 'Protecting Europe: policies for enhancing security in the EU', Brussels, 30 May 2006

Georgieva, K. (2011a)'Policy Priorities - achievements and mapping the ways ahead', Development Committee, European Parliament, 25 May 2011

Georgieva, K. (2011b) 'Challenges and Priorities for Humanitarian Action: A European Perspective', Opening address on the occasion of the French National Conference on Humanitarian Aid, Paris, 16 November 2011 
Glasius, M. (2008), 'Human Security from Paradigm Shift to Operationalization: Job Description for a Human Security Worker', Security Dialogue, 39, 2008, p. 3154

Glasius, M. and Kaldor, M. (2006), A Human Security Doctrine for Europe: Project, Principles, Practicalities, London and New York: Routledge, p.6

Glasius, M. and Kaldor, M. (2005) 'Individuals first: a human security doctrine for the European Union', Internationale Politik and Gesellchaft (IPG) I, 2005, p.67

Helsinki Plus Report (2010), 'Helsinki Plus: Towards a Human Security Architecture for Europe', May 2010, the First Report of the EU-Russia Human Security Study Group

Human Security Now, (2001) The Commission on Human Security

Kaldor, M. (2010), 'AN INTERVIEW WITH MARY KALDOR', From Volume 5, Issue 2 - Spring/Summer 2010: Spotlight on Security. Available online: http://yalejournal.org/2010/07/putting-people-first-the-growing-influence-of\%E2\%80\%98human-security\%E2\%80\%99/ (accessed February 2012)

Kotsopoulos, J. (2007) 'A human security agenda for the EU: would it make a difference?', Studia Diplomatica, vol. 60, issue 1, 2007, p.213-231. 
Kotsopoulos, J. (2006), ‘A human security agenda for the EU?', EPC Issue Paper No.48, June 2006, p.5-22

Kuhne, H. (2008) 'Report on the implementation of the European Security Strategy and ESDP', European Parliament, Committee on Foreign Affairs, 15 May 2008

Liotta, P.H. and Owen, T. (2006) 'Why Human Security?', The Whitehead Journal of Diplomacy and International Relations, Winter/Spring 2006, p.43

MacFarlane, N. and Khong, Y.F. (2006) Human Security and the UN: A Critical History, Bloomington, IN: Indiana University Press

Martin, M. and Kaldor, M. (2010) The European Union and Human Security: External interventions and missions, Routledge Studies in Human Security, London and New York: Routledge

Martin, M. and Taylor, O, (2010), 'The second generation of human security: lessons from the UN and EU experience', International Affairs, 86: 1, 2010, pp. 211-224.

Matlary,J.H. (2008), 'Much ado about little: the EU and human security', International Affairs, 84: 1, 2008, pp.131-143 
Owen, T. (2008) 'The Critique that Doesn't Bite: A Response to David Chandler's 'Human Security: The Dog That Didn't Bark', Security Dialogue, 39, 2008, pp. $445-453$

Paris, R. (2004) 'Still an Inscrutable Concept', in J. Peter Burgess and Taylor Owen (eds) 'Special Section: What is "Human Security", Security Dialogue, 35 (3), pp.370-2;

Paris, R. (2001) ‘Human Security: Paradigm Shift or Hot Air?', International Security, 26 (2) (Fall 2001), pp87-102

Pielbags, A. (2011), 'The future of development policy and budget support', Conference, Brussels, Speech/11/685, 19 October 2011

Report on the Implementation of the European Security Strategy-Providing Security in a Changing World, Brussels, 11 December 2008, S407/08.

Available online at:

http://www.consilium.europa.eu/ueDocs/cms_Data/docs/pressdata/EN/reports/1046

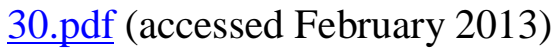

Rothschild, E. (1995), 'What is security?, Daedalus - Journal of the American Association for the Advancement of Science, 124 (3), 1995, pp.53-98

Solana, J. and Kaldor, M. discuss human security in Madrid (2007), Security and World Politics [11/08/2007]. Available online at: 
http://www.cidob.org/en/news/security and world politics/javier solana and mar

y kaldor discuss human security in madrid (Accessed February 2013)

Solana, J. (2005) 'Shaping an Effective EU Foreign Policy', Speech by Javier Solana at the Konrad Adenaur Foundation (Brussels), 24 January, 2005.

Solana, J. (2004), 'EUHR Solana Responds to report by Study Group on Europe's Security Capabilities', Brussels, 16 September, 2004. Available online at: http://www.eu-un.europa.eu/articles/fr/article 3814 fr.htm (accessed March 2013)

Suhrke, A. 'Human Security and the Interests of States', Security Dialogue, 30 (3), 1999, pp. 265-276

'Towards A European Global Strategy: Securing European Influence in a Changing World' (2013). Available at:

http://www.europeanglobalstrategy.eu/nyheter/publications (accessed June 2013)

UNDP-UNU-CRIS, (2009) 'Delivering Human Security through multi-level

Governance', Published by United Nations University - Comparative Regional Integration Studies (UNU-CRIS), United Nations Development Programme (UNDP)

United Nations Development Report (1994), United Nations Development Programme (UNDPHDR), New York, Oxford: Oxford University Press 